\title{
Resistance and Media: "Toma" as a Metaphor of Power Relations and its Representation in Northern Cyprus Print Media
}

\author{
Tutku AKTER, GAU, TRNC
}

\begin{abstract}
The Cyprus Island's political issues, both internal and external, have a huge role at the predestination of the Island. Hence, there have been ongoing negotiations since 2003 about the reunification of the Island. In this regard, it is indispensable to consider the role of media punctiliously, and to understand how power relations work. This article examines discussions about bringing 'TOMA' (as 'Riot Control Vehicle') to the Northern Cyprus as a metaphor of power relations between Cyprus and Turkey. Whether or not newspapers from different ideologies would meet on a common ground in case of a situation that may threaten social structure and order, is identified as the research problem. The finding is that within particular circumstances, the media may function as a means of resistance and social struggle against external factors.
\end{abstract}

Keywords: Public opinion, resistance, TOMA, power relations, media, critical analysis 
McCombs and Shaw first proposed the agenda-setting function of mass media in the1970s. Based on their research, they declared that by setting the agenda, 'recipients' do not only learn what has been given to them, but also learn the significance of what has been given to the audiences. They also maintained that "most of what people know come to them as 'second' or 'third' hand information from the mass media or from other people” (1972:176).

The authors argued that the agenda-setting paradigm is related to 'bandwagon,' 'spiral of silence' 'propaganda' and 'diffusion of news.' Moreover, as Severin and Tankard (2001) also mentioned, the findings of McCombs and Shaw supported an agenda-setting effect on the audiences. Their data strongly pointed out a relationship between the media emphasis on an issue and the audience perception of the issue (Akter, 2012).

In addition to this, some scholars such as Rogers and Dearing (1996) stated that people are 'primed' about 'what issues to think about' via the agenda-setting process. Public agenda setting investigates an indirect effect of media as 'what to think about' rather than a direct effect that focuses on 'what to think.' They also strengthen the argument by stressing the fact that "the sources of news are issue proponents, for the purpose of pushing a cause, promoting a vision or value system, or publishing an organization" (Rogers and Dearing, 1996:25). It is necessary to pose some questions to clarify the knowledge, which is given to the audiences or students as recipients, such as 'who sets the agenda' and 'what are the external factors that influence the process of setting the agenda' (Akter, 2012).

Coleman, R., McCombs, M., Shaw, D. and Weaver, D. (2009) noted that the roots of agendasetting theory have been credited to Lippmann who maintained that the news media construct our world view in his book Public Opinion in 1922. Soon after, 50 years later, McCombs and Shaw gave name to this phenomenon that was described by Lippmann previously, and called it 'agenda setting'.

As Coleman et al. also claimed, agenda setting can be described as "the process of media presenting certain issues frequently and prominently with the result that large segments of the public come to perceive those issues as more important than others" (Coleman, R., McCombs, M., Shaw, D. and Weaver, D., 2009: 147). Moreover, the priority of issues on the 
public agenda can be influenced easily by the priority of issues on the media agenda (Kwansah- Aidoo, 2005).

As it is known, one of the vital roles of mass media is to inform people and educate as well as entertain them. However, media, which are closely related to socio-economic and political issues, cannot be examined as absolute and innocent arbitrators.

Silverblatt and Eliceiri (1997) claimed that the source of the coverage, when it is given as well as the issues that are covered and the priorities that are given to certain matters in the media, and the ones that are covered on a sustained basis, encompass the agenda-setting power of mass media. Authors talked about three factors that might be responsible for the agenda-setting function. These are (1) 'perceived credibility of the media', (2) 'reliance on media for information' as well as (3) 'exposure to media message' (Silverblatt and Eliceiri, 1997: 4).

Agenda setting is also explained as "the process by which problems become salient as political issues, around which policy alternatives can be defined, and support or opposition is gathered" (O'Heffernan, 1991: 45). Via the settled agenda, interest groups or media owners may center upon any issue that they want. Here, it is noteworthy to distinguish media agenda setting and public agenda setting. As the name suggests, media agenda is about setting the priority of the issues on the media agenda while public agenda is all about the priorities of the public. As also mentioned by McCombs (2002), it is 'the focus of public attention' and it is frequently considered by public opinion polls that ask some discrepancy of the established opinion survey question such as "What is the most important problem facing this country today?" However, beyond the shadow of a doubt, media agenda has influences on the formation of public opinion and as well as on the public agenda. McQuail (1987) categorized the social functions of media as information, correlations, continuity, entertainment, and mobilization.

Information function refers to world events, power relations, progress, and innovation. Correlations draws attention to clarifying and illuminating events and to building of consensus while the continuity function expresses culture and national identity. With entertainment, the media may be reduced to a form of relaxation. Lastly, social objectives, 
politics, and war are included in the mobilization function. Hence, integration, coordination, control, stability, mobilization, tension, thoughts, values, discipline, and conformity as also claimed by Mehdizadeh (2010) can be managed to some degree by mass media. As mentioned previously, via the settled agenda, mass media do not tell people what to think, but they tell people what to think about. As agenda indicates the priority of the issue, by setting it through the interests of dominant groups or the one who has control over the media, it would be easier to manipulate public opinion. Therefore, it is possible to claim that media agenda and public agenda are articulated to each other. As news media's considerable influence on the public agenda's content is clarified, and the expression 'setting the agenda' has become conventional in discussions of journalism and public opinion (McCombs, 2002). During the present study, in order to figure out how mass media do set their agenda and to examine the structure of the discourses they prefer to express themselves, the hard news of each newspaper particularly, were examined through critical discourse analysis.

\section{Formation of Public Opinion via Mass Media and Ideology}

Not only by bringing particular issues into question, but also by the content and context of the issue or via its treatment, people can be manipulated. Whereas news is not even absolute reflections of what had happened, but re-construction of the realities, it would be adequate to insist on the manipulative power of mass media. As it is known, media do not only focus the public attention on a particular topic, but also influence our understanding and perspective on the topics in the news (McCombs, 2002). Katz (1995), while highlighting the fact that there are various definitions of 'public opinion,' refers to Robinson and Iyangar's perspectives to clarify the distinction between definitions. The author adds that dominant opinion can be assumed as the 'cause' of news discourse from Robinson's perspective, but as 'the result' of news framing from Iyangar's point of view.

Through the dominant ideologies or the interests of the ruling class, people might be reshaped or reformed by setting the agenda of the mass media. In other words, ownership and control of mass media, as an 'ideological gun,' plays a significant role in the process of manipulating 'publics' or 'masses,' cultivating ideas and even reconstructing 'realities' and 'public opinion.' According to Noelle-Neumann, as cited in Scheufele and Moy (1999), public opinion can be categorized into two different contexts: public opinion as rationality and public opinion as social control. The rationale formation of public opinion occurs when most 
of the citizens agree on a view that individuals have arrived at owing to either the reflection or knowledge of an issue. It is also vital for social change. However, public opinion as social control underlines the spiral of silence theory because social mechanisms pressurize persons with social isolation. Thus, this version defines public opinion as views that can be expressed without fear of isolation or views that are expressed to avoid isolation.

Public opinion as rationality and public opinion as social control differ in three aspects: modes of opinion expression, respect of the opinion, and the conceptualization of the term 'public.' According to Scheufele and Moy (1999), the rationale formation of public opinion is mainly stressed by the verbal expression of rational opinions while public opinion as social control works through altered modes of opinion expression like verbal and facial expressions, signs, and openly visible symbols. In the rationale formation of public opinion, the public is more knowingly aware as it has the ability to receive information and has the enthusiasm for discussions. However, with public opinion as social control, people observe their environment without thinking to find out the present and future circulation of views.

Finally, in the rationale model of public opinion, the 'public' refers to a specific group that is politically interested and well-informed, while in social control model, it refers not only to a particular group, but rather to all members of the society. Mass media, which spread the knowledge to a large number of people, are used to form public opinion. Many stereotypes are involved within the texts of mass media. However, people are generally not conscious of the influence of the owners of mass media or the leading groups that manage the circulation of knowledge through mass media. Stereotypes that are placed at the core of the codes predetermine what to think or not to think about an issue. Hence, 'what is ignored' and 'what is placed' are the key within the descriptions that are used in the complexity of reality. Based on the results of this selection process, the present study assumes that relating to reality is more significant than what the reality is. The 'events' that are reflected are just not lies, but are the reconstructions of some parts of the reality. In such a case, it may overlap with the concept of 'false consciousness' as proposed by Marxism. Therefore, as mentioned above, audiences may be influenced by the 'realities' constructed through the interests of the control groups or the media owners. There are various theories that investigate whether the way in which mass media is used is an 'ideological means of communication' or a 'means of communication in the way of forming social integration.' 
Ideology is defined as a broad interlocked set of ideas and beliefs about the world held by a group of people, and that they demonstrate in both behaviour and conversation to various audiences. These systems of belief are usually seen as 'the way things really are' by the groups holding them, and they become the taken-for-granted ways of making sense of the world (Meighan et al., 2007: 212). Literally, there are various definitions of ideology. One of the main distinctions between the definitions is related to 'perception' of the term within certain circumstances. For instance, while Hall (1996: 26) defines ideology as a "mental frameworks - the languages, the concepts, categories, imagery of thought, and the systems of representation - which different classes and social groups deploy in order to make sense of, figure out and render intelligible the way society works", Williams explained it in three aspects: “(i) a system of beliefs characteristic of a particular class or group; (ii) a system of illusory beliefs, false ideas or false consciousness which can be contrasted with true or scientific knowledge; and (iii) the general process of the production of meanings and ideas" (Williams 1977/1988: 54).

In addition to this, Althusser handles ideology from different perspectives and claims that it is "the name given to any comprehensive and mutually consistent set of ideas by which a social group makes sense of the world" (Althusser, 1971: 162). Therefore, Althusser assumes that an individual's lived experiences are expressed by ideology and claims the fact that practical behaviours which 'recommend' representations to help people live their lives, empower the ideology. Destutt de Tracy was the one who introduced the term 'ideology' in 1796 and conceptualized the term to point at a critical science that intended on following the accurate natural science model to study ideas into basic parts while investigating the perceptions upon which they were found (Rehmann, J 2013). According to him, the concept of ideology bears a positive meaning. He insisted that it was possible to observe the existing reality and to reach 'reality' in social sciences, as in natural science, via rationality and methods.

Karl Marx and Friedrich Engels also dealt with ideology as a term four decades later. The Marxist ideology, unlike De Tracy, accepts ideology as an instrument for social production. Marxist ideology deals with the production of reality and insisted that ideology created 'false consciousness' but never claimed it in these words. Marx and Engels (who were the first to use the term 'false consciousness') insisted that ideology should be accepted as a process 
accomplished consciously by the thinker, indeed, but with a false consciousness (Akter, T., 2012). Unlike Destutt de Tracy, from the Marxist point of view, ideology bears a negative meaning. Therefore, it insists on the fact that reality is produced. According to them, ideology was closely connected to idealism and idealism was accepted as a problematic approach, which linked the unequal distribution of power relations and resources. To put it in a different way, it was claimed that social and economic regulations were defective and so ideology, as a part of them, was also defective. According to the Marxist view, dominant ideas were the ideas of the dominant classes at every single period. Further, only the ideas that 'camouflage' and naturalize the real nature of socio-economic relations would form 'ideology.' Marx maintained that ideology was a 'shadow-like' illusion - that an idea was the shady illustration of a real thing. He also claimed that it was an outcome of the capitalist social relations and was devoted to cover up the basic production relations. In essence, a combination of elements preserves class relations. In other words, Marx talked about 'deceptive' expression of 'reality' and restructuring of the social world by such false reflections of the 'reality.' Thus, ideologies were handled as in relation with social relations.

Within this context, the dominant group, which diffuses the ideologies, mostly owns or controls the means that enable them to diffuse their ideas. Therefore, they inject their own ideas to the rest and may create 'false consciousness.' Thus, briefly, ideology can be defined as an "integrated set of beliefs about the social and political environment" (Connolly, W. E. 2006: 2). Therefore, it would be possible to emphasize the effective power of the dominant political party or ruling class ideologies on each socio-cultural and political pattern. Primarily, these effects or influences ${ }^{1}$ can be observed as operating of mechanisms that circle the main system. In this research, newspapers, as a mean of mass media as well as socio-cultural mechanisms and their interaction processes with dominant ideologies within the qualitative context, are explored.

Riot-Control Vehicle as a Means of 'Power Relations' and Intervention Directed to Local Regime

\footnotetext{
${ }^{1}$ The term effect is used mostly by mainstream scholars who defend the active role of recipients, while influence is used by critical thinkers to underline that recipients are 'passivated.' Distinction is based on the awareness of the recipients.
} 
The Cyprus issue is not limited only to the problem that was started with ENOSIS that was the intention of Greece to add Cyprus into her land or to the problem between Turkey and Greece. To understand the Cyprus issue in terms of relations between Turkey and Northern Cyprus, it is essential to know the history of the island. It is an issue in the sense of political, social, identical, or economic aspects that have been negotiated for a long time by various nations. Because of its socio-political and strategic positions, as can be traced from its historical background, in the past years, the Cyprus Island had played a part in the joint line of various nations (Akter, 2013).

As stated in the Warranty Agreement, which was signed on the $11^{\text {th }}$ of February 1959, Turkey, Greece, and England have been declared as guarantor countries of the Cyprus Island. This agreement noticeably prevents any direct or indirect act by these countries, which may affect the future of the Island. However, any intervention, whether directly or indirectly aimed at the regime of the nation that lives in the mentioned Island, should be handled within the context of 'affecting the future of the Island'. In this study, TOMAs, which particularly gained currency after the 'Gezi Park' protests that took place in Turkey (May 2013), will be dealt as the metaphor of 'power relations' because TOMAs were used by the government to 'appease' the protests of activists. Due to this, the responses of local newspapers (both leftist and rightist) to the 'idea of bringing TOMA' to Northern Cyprus will be examined.

To deal with such an issue, it is important to investigate the response of local media to any sort of external 'intervention' and thus, the general attitude of the nation who lives in Northern Cyprus in case of any situation that may influence the 'regime' and thus, may directly affect the future of the Island. Because ideology can refer to "simply coherent and powerful set of ideas, but tends to mean systems of representations which work in the interests of certain groups, often the most powerful, and which present themselves as unmotivated and commonsensical" (Matheson, 2005: 179), it cannot be distinguished from the mass media which can be assumed as a means of ideology.

As Thompson (1984) also claimed, there is a close relationship between the theory of ideology and language studies. He suggests that ideology mostly examines the ways in which meaning and ideas may affect the perceptions or manners of people. Within this context, two most known local newspapers from Northern Cyprus, Afrika (leftist) and Volkan (rightist), 
are analyzed for the purpose of this study. In this regard, local newspapers' responses, as 'constructed' voice of local people, to the metaphor of 'power relations' and general attitude to the idea of bringing TOMA to Northern Cyprus are examined through critical analysis. Whether or not the local press supports the existing government and its external relations as well as its politics under all conditions will be clarified through the comparative discourse analysis of an issue, which is handled as a metaphor of power relations and government pressure. However, note that it would not be adequate to generalize the results of the present study unless supportive and related studies are going to be done in the future. The present study questioned whether or not newspapers from different ideologies would have similar publishing policies at handling an issue that may threaten socio-cultural system of the country.

\section{Results}

To provide clear understanding about the assumed influences of media text on audiences, the discourses of particular news are comparatively analyzed. Basically, the interrelation between ideology and the structure of given information is figured out as well as emphasizing the possibility of having consensus on 'discourses' in terms of defending or forming public opinion at particular situations that might be 'assumed' as a threat for socio-cultural structure. Critical discourse analysis which is defined as "a type of discourse analytical research that primarily studies the way social power abuse, dominance, and inequality are enacted, reproduced, and resisted by text and talk in the social and political context" (Van Dijk, 2001: 352 ) is the method used in this study. Correspondingly, discourses on hard news of local print media, particularly the news about bringing 'TOMA' to Northern Cyprus are analyzed. Hard news and thus, the agenda of Afrika (leftist) and Volkan (rightist) newspapers which have different ideologies are comparatively investigated for two weeks.

\section{Case Study}

Comparative and critical analyses of the Afrika (leftist) and Volkan (rightist) newspapers were carried out. During the study, in terms of analyzing knowledge construction about the issue, hard news related to bringing TOMA to Northern Cyprus were examined. The cover pages of the Afrika and Volkan newspapers that were published between the $13^{\text {rd }}$ and $21^{\text {st }}$ of September were comparatively analyzed. 


\section{Representations of 'TOMA' in Northern Cyprus Print Media as a Metaphor of Power}

\section{Relations}

\section{First 5 days' reflection: 13 - 17 September 2013}

As a result of the analysis, it is noted that there was no related news at the coverage of Volkan Newspaper about bringing TOMA to Northern Cyprus. Volkan, which is known as one of the most rightist newspapers, has maintained its silence for the first 5 days.

On the other hand, the 'idea of bringing TOMA to Northern Cyprus' was in the first page of the Afrika Newspaper not only for the first 5 days, but for 9 days. Afrika is one of the leftist newspapers, which is also known as adversary press, settled this 'issue' both to its own agenda and that of the public agenda.

13 September in Afrika. The news was given the headline "PROMISE OF TOMA" with one of the most known photos from the Gezi Park protests, which seemingly denotes that it isto be used against people (see Figure 1). Actually, the headline itself needs to be investigated within the context of 'who' promises 'what' and 'to whom.' This interrelation indicates the unknown or implicit power relations and privity, but it has been left open to interpretation.

More interestingly, the speech of Prime Minister, Mr. Ozkan Yorgancioglu, about claiming that he had no idea about this issue and promising not to use it against the public was reported next to the given photo. Contradiction between the given visual image and the text indicates the mistrust of the newspaper's authorities. Afrika was questioning the reason of bringing TOMA to Northern Cyprus, if it's not going to be used against social events.

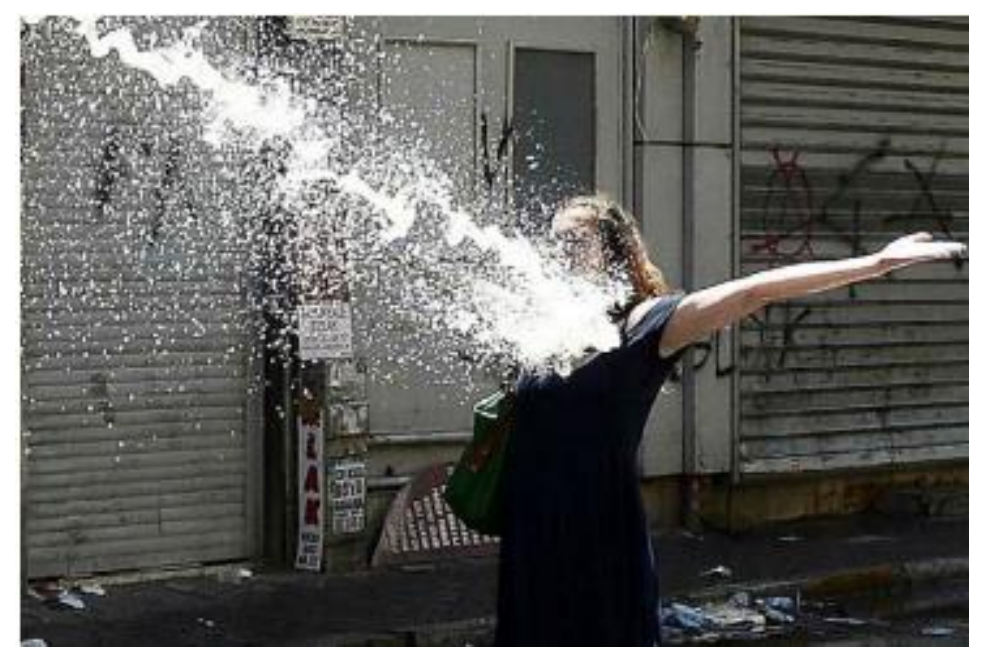

Figure 1. Woman versus water cannon. (Afrika Newspaper,13.09.2013) 
Reflections on 14 September. On this day, the TOMA issue was on the cover page again, but it was a small column, without a picture, but only with a headline "Snowballing reactions to TOMA" with white letters on black background. Declarations and critics of political leaders from leftist parties about the issue were given under this headline. One of these political leaders was Elcil, who is the General Secretary of Turkish Cypriot Teacher's Union, was complaining and highlighting the lack of some services by stating 'no money for education, but building mosque or Koran courses of religious sects and finally for TOMA...' (His declaration was given in bold black font) and another statement claiming that they will take a stand against followers of AKP to justify that the idea of bringing TOMA to Northern Cyprus is 'indirectly' from Turkey's current government. Furthermore, the Chairman of the Socialist Democracy Party (TDP) Ozyigit's approach to the issue was paraphrased as "Prime Minister should make a clearer statement... It is important to prevent the entrance of this vehicle to the Island...." to show his opposition not only to the purpose of bringing the vehicle, but to the idea itself.

The United Cyprus Party (BKP) made a statement about the necessity of cancelling the TOMA purchase immediately and about the ridiculousness of what Yorgancioglu said. The Air Traffic Controller Association (HTKS), which was also opposed to the idea of bringing TOMA to the Island, also had a final statement: "How people can be tortured by TOMA was proven in Gezi Park Protests... It is produced by dictatorship mentality..."

Silence on 15 September. The results showed that the 'idea of bringing TOMA to Northern Cyprus' was placed neither in Afrika nor in Volkan's first pages, while the issue took a great space in the following days' hard news of Afrika.

Breaking the silence on 16 September. Before the headline "Either resignation or TOMA", Afrika recalls the General Secretary of the Republican Turkish Party Asin Aksoy's statement and criticizes him about remaining unresponsive although declaring that he will resign in case of the arrival of TOMA to this country. The headline itself, reminded of a saying by Turkish Leader Ataturk, "Either freedom or death". Therefore, within this context, TOMA is identified as 'death,' figuratively speaking. Ironically, the headline had the subtitle "Soda water for the faint one, TOMA for the one who comes around." 
Furthermore, the Prime Minister of the National Unity Party, Huseyin Orgurgun's speech, which was based on criticizing the existing government andits promise about preventing the entrance of the vehicle to the country was included in the paper. Afrika wanted to highlight the opposition of the majority of the Turkish Cypriot society regardless of its ideology or political view by including the rightist political party's approaches about the issue.

Reflections on 17 September. Nevertheless, while Volkan maintained its silence; the issue was again placed in the cover page of Afrika. Ozkan Yorgancioglu was included in the agenda of the newspaper and his statements were reflected. "First action against TOMA is from Ozkan Yorgancioglu" was one of the headlines, just right before "he will use his chest as a shield against to TOMA". Then, his speeches at the parliament were paraphrased and stated that he declared that he would stand at the customhouse to prevent its entrance, if needed.

\section{Last 4 days' reflection: 18 - 21 September 2013}

18 September: Afrika vs. Volkan. At the top of the cover page, the challenge of Afrika was clarified by stating "For Tayyip's information...one TOMA is not enough for us, we would like at least six... Also few scorpions, plenty of gas bombs and rubber bullets. If you haven't recognized Cypriot warriors yet, you will."

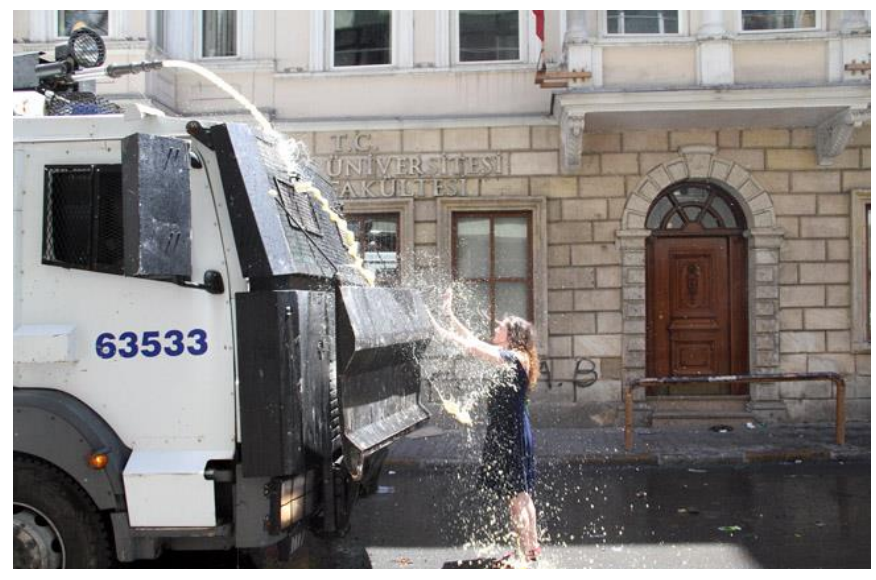

Figure 2. Woman resisting TOMA (Volkan Newspaper, 18.09.2013)

On this day, Afrika laid down that the idea of bringing TOMA into Northern Cyprus was totally the imposition of AKP not of the security forces command (GKK) of Northern Cyprus. Then, on the left side of the photo of Yorgancioglu and GKK commander Kavun while shaking hands, a question was raised as 'who is authorized?' then replied as 'none of them' to 
highlight that neither political leaders nor the security forces command of the Island have the right to speak or to make decisions about the issue. On the right side of this photo, the statement of Sibel Siber, the president of the assembly, is placed with a headline "Society does not need TOMA." In the next headline, it was justified that the issue about TOMAwas passed on to AKP. While declaring the visit of Kavun, it was highlighted that no information was given about whether the TOMA issue was discussed or not during that visit, but after the next meeting, Yorgancioglu's statement about the possibility of arriving at an agreement between the parties was highlighted. On the bottom right, the declaration of nongovernmentalorganisation 'Toparlaniyoruz' (we are recovering) was included, with an appeal to cancel the TOMA agreement.

On the other hand, for the first time, Volkan discussed this issue on 18 September. As with Afrika, photos from the Gezi Park protests were placed on the cover page; one was similar to what was in Afrika (see Figure 1) and the rest were also related to the same protest, which justified the identification of TOMA with Gezi Park protests as the metaphor of power relations and as repressive state apparatuses.

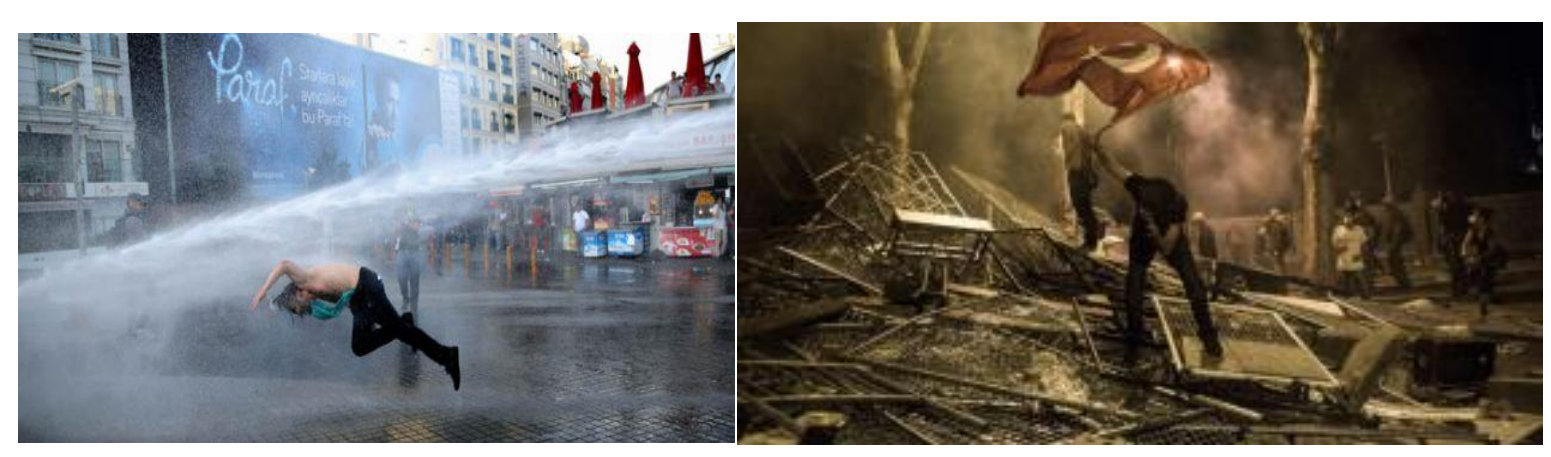

Figure 3. TOMA against Gezi Park protesters (Volkan Newspaper, 18.09.13)

However, Volkan, as one of the most nationalist newspapers, emphasized national feelings and nationalism at even such an event by placing a photo including the Turkish flag. By this photo, Volkan also showed a supportive attitude toward the independence and sovereignty of the secular Turkish society while resisting conservative and repressive rule. The first and the biggest headline highlighted the disturbance caused by the TOMA issue., Then, there was no statement after Kavun's visit to Yorgancioglu. In addition to this, like with Afrika, Sibel Siber's statement was included in the paper as a declaration of non-governmental organization 
'Toparlaniyoruz' and public unions were given space in the paper. Due to this, it was clarified that both newspapers maintained the same attitude about the issue: 'resistance'.

19 September. In the bottom-center of Afrika, there was a picture of Yorgancioglu and news that was entitled "Discussions regarding TOMA continue, cancellation is asked from the Command". The statement of Yorgancioglu followed "Sensitivity depicted with the relevant authorities" even though the identity of the authorities was not disclosed; predictably, it was the Command of Northern Cyprus. It was also noted that no certain reply was received yet and that the final decision would be made by AKP. Thus, authorities of the newspaper addressed Turkey again, while giving space to recrimination of local political parties (CTP ${ }^{2}$ and $\mathrm{UBP}^{3}$ ). The main accusation was about making a tender of TOMA, which was done by UBP when they were still the governing body, and then Akansoy's (member of the parliament from CTP) statement about denying that he will resign in case of the purchase of TOMA. Authorities of the newspaper tried to emphasize the speciousness of political leaders via highlighting how they were breaking their words by correcting or retracting their previous statements. On the other hand, Volkan also allocated a small space on the issue on the top of the page with the headline "Purchasing TOMA instruction is given by police department". In view of the reactions to the Government and authorities regarding who was responsible for the purchase decision, and on shifting the responsibility from one to another, it was declared in the news that this decision was made by the General Police Directorate. Furthermore, as stated in Afrika, Yorgancioglu's averseness regarding the situation was highlighted in Volkan.

According to the declaration made by authorized people, it would be enough to bring the situation to the Cabinet agenda and to cancel the purchase by paying compensation back to the relevant company. Because of the consistency reflected in Yorgancioglu's attitude towards the situation, credibility is created in readers of both newspapers.

20 September: 'Inability' vs. the silence of Volkan. "Inability" was the biggest headline of Afrika on this day. It was noted that the Government's " Inability " could not shake the issue of the TOMA dilemma. Moreover, Afrika's authorities claimed that "Recep Tayyip Erdogan who stated that policemen made history by using gas bombs, tear gas and TOMA against Gezi

\footnotetext{
${ }^{2}$ Cumhuriyetci Turk Partisi (Republican Turkish Party), leftist party of Northern Cyprus.

${ }^{3}$ Ulusal Birlik Partisi (National Unity Party), rightist party of Northern Cyprus.
} 
Park protesters, is planning to bring Turkish Cypriots into alignment with same method. He is trying to design the police department in Cyprus in the same way in Turkey". This declaration, directly and clearly shows that TOMA is the metaphor of power relations in Turkey by looking at it as apparatuses of oppressive state. A photo of TOMA vehicle was again displayed as if an 'alleged criminal' (Figure 4); however, the vehicle was referring to the personalized authority of an oppressive state.

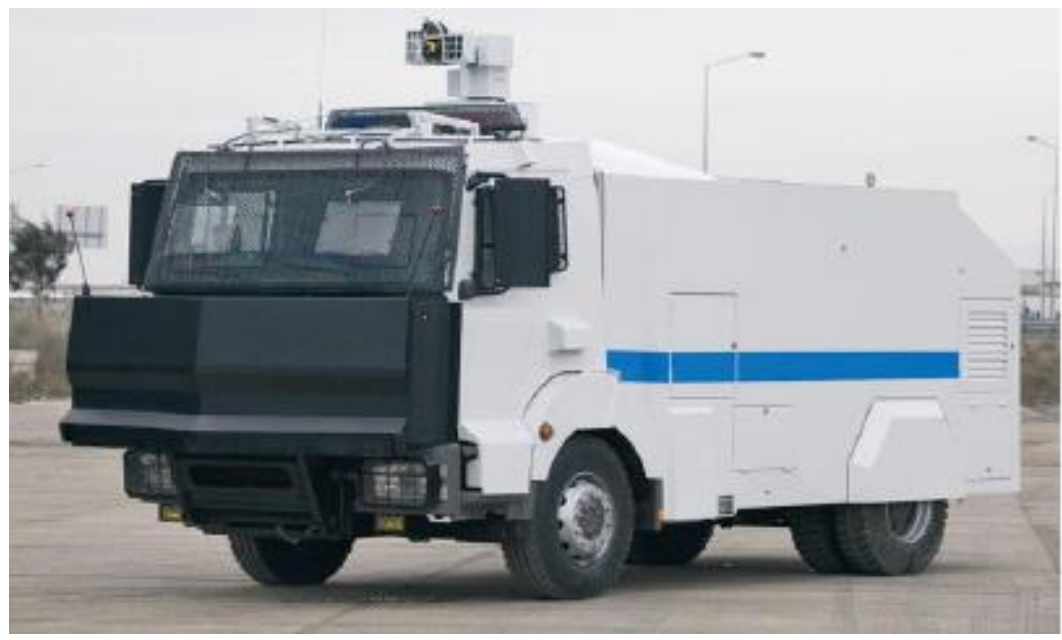

Figure 4. Personalized authority of an oppressive state: the alleged criminal

21 September. The biggest headline of Afrika“And TOMA cancellation" was like giving the Turkish Cypriots a piece of good news. Under this headline, it was noted that the previous morning, Yorgancioglu held a press conference and announced the decision, as if it were a gospel. He also decelerated that they came to an agreement about the issue and thanked them. Then, Yorgancioglu appealed to change the agenda and to deal with other issues of government. The agenda of the newspaper shifted to argument about the flight of Trabzonspor which was going to land directly to Southern Cyprus.

The space thatwas given to the withdrawal of bringing TOMA into Northern Cyprus was at the top of the cover page, but it was very small at Volkan. The declaration of Yorgancioglu about doing the right thing finally, which had to be done at the beginning of the process was included. In addition to this, a picture was placed next to the news of 18 September. However, instead of showing a real photo of the vehicle, only its illustration (Figure 5) was provided to soften the severity of the situation. 


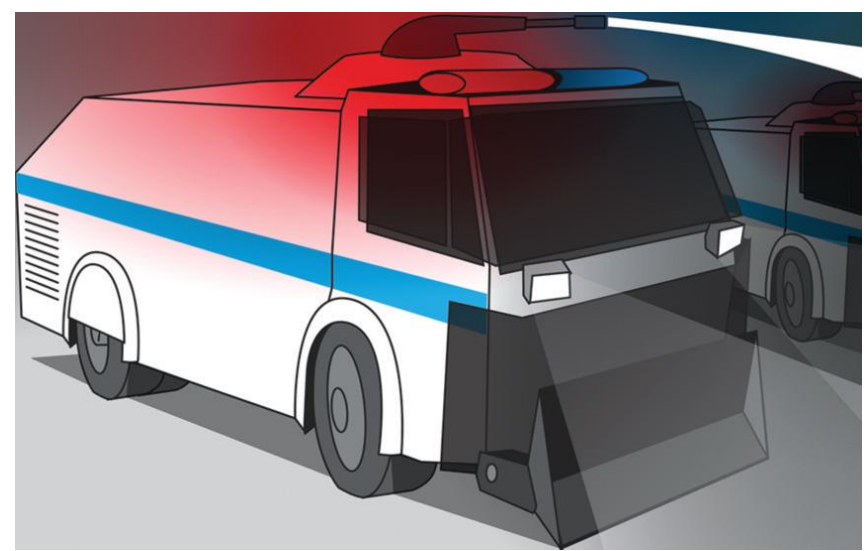

Figure 5. Illustration of TOMA (Volkan Newspaper, 21.09.2013)

\section{Conclusion and Further Suggestions}

As a result of the investigation, it was noted that the two newspapers as ideological state apparatuses, although having opposed broadcasting policies and ideologies, could make a consensus and agree on all hands against the external forces. Media organs which have the power to create public opinion, within this context, keep molding an opinion as a 'resistance' against 'external' effects. The similarity between the policies of two adversary media organs, Afrika and Volkan, towards the event in question, surely does not represent the opinion of the Turkish Cypriots, but an opinion that was created. An indication of this created opinion was not only giving the issue an important place and space in the papers, but their treatment policy as well. In general, TOMA is seen as a vehicle that is used by policemen (as an apparatus of an oppressive state) against the public, and is also identified with the mode of operation of power relations by emphasizing Gezi Park protests.

Based on the results obtained, the "inessentiality" of bringing TOMA to Northern Cyprus and the "inconveniency" of the idea were stressed by both newspapers. Their resistance against the external power relations and their effects was supported by photos that were used. In summary, it was clarified that newspapers with different ideologies and policies could have similar publishing policies on handling certain issues such as evidenced by this issue of "bringing TOMA" to Northern Cyprus because it was seen as a "threat" to the stability of the socio-cultural system. As mentioned previously, newspapers may not change their policies to "mold the public opinion" to reflect the "public" opinion, but they may lead the public to resist and collaborate against critical issues. Because there is a relationship between the media emphasis on an issue and the audience perception, it is possible to assume that newspapers 
may not reflect the opinion of the public, but they may influence how they do perceive the issue.

\section{References}

Akter, T. (October 2012). Knowledge as the Victim of Negotiation: An Exploratory Study of the National Identity Construction in the Cyprus History. Estonia: Lambert Academic Publishing

Akter, T. (May 2013). Social perception of Cyprian Facebook users in Northern Cyprus: Reconsideration of social structure and particularly residents of Northern Cyprus. $2^{\text {nd }}$ International Conference on Communication, Media, Technology and Design. ICCMTD. Famagusta/Cyprus

Althusser, L. (1971). Lenin and Philosophy. New York: Monthly Review.

Coleman, R., McCombs, M., Shaw, D. and Weaver, D. (2009). Agenda Setting. In K. WahlJorgensen, \& T. Ianitzsch, The Handbook of Journalism Studies (pp. 147-161). New York: Routhedge.

Connolly, W. E. (2006). Political Science and Ideology. New York : Aldine Transaction Publication

Kwansah-Aidoo, K. (2005). Topical issues in communications and media research. New York: Nova Science Publishers.

Katz, E., (1995). 'Introduction: The State of the Art'. In Glasser, T. L., Katz, E., \& Salmon, C.

T. (Eds). Public opinion and the communication of consent. New York [u.a.: Guilford Press.. xxi-xxxiv.

Hall, S. (1996) 'The problem of ideology: Marxism without guarantees', in D. Morley and 
K.H. Chen (eds), Stuart Hall: Critical Dialogues in Cultural Studies. London: Routledge. pp. 25-46. (Earlier published in B. Matthews (ed.) (1983) Marx: 100 Years On. London: Lawrence and Wishart. pp. 57-84.)

Meighan, R. et al. (2007) A Sociology of Educating, London: Continuum.

Rehmann, J. (2007). Ideology Theory. In Historical Materialism 15. 211-239.

http://www.inkrit.de/hkwm-int/aritcles/IdeologyTheory.pdf

O'Heffernan, P. (1991). Mass media and American foreign policy: Insider perspectives on global journalism and the foreign policy process. Norwood, NJ: Ablex Pub.

Matheson, D. (2005). Media discourses: Analysing media texts. Maidenhead: Open University Press.

McCombs, M. E. \& Shaw, D. L. (1972). The Agenda-Setting Function of Mass Media. In Public opinion quarterly. XXXVI, 2.

McCombs, M. (2002, June). The agenda-setting role of the mass media in the shaping of public opinion. In Mass Media Economics 2002 Conference, London School of Economics: http://sticerd. lse. ac. uk/dps/extra/McCombs. pdf.

McQuail, D. (1987). Mass communication theory: An introduction. London: Sage.

Mehdizadeh, M. (2010). The theories of media: Current thoughts and critical attitudes. Hamshahri press, Tehran. pp: 147-148

Rehmann, J. (2013). Theories of ideology: The powers of alienation and subjection. Leiden [etc.: Brill.

Rogers, R. (2004). An introduction to Critical Discourse Analysis in Education. Mahwah, New Jersey: Lawrence Erlbaum Associates

Scheufele, D.A.; Moy, P. (1999). Twenty-five years of the spiral of silence: a conceptual review and empirical outlook. International Journal of Public Opinion Research, 1, 954-982.

Severin, W. J. \& Tankard, J. W. JR. (2001). Communication Theories: Origins, Methods, and Uses in the Mass Media. New York: Longman Publications.

Silverblatt, A., \& Eliceiri, E. M. E. (1997). Dictionary of media literacy. Westport, Conn. [u.a.: Greenwood Press.

Thompson, J. B. (1984). Studies in the theory of ideology. Berkeley: University of California Press. 
Van Dijk, T. A. (2001). 18 Critical discourse analysis. In The handbook of discourse analysis. Schiffrin, D., Tannen, D., \& Hamilton, H. E. eds. Malden, Mass: Blackwell Publishers.

Williams, Raymond. 1977/1988. Marxism and Literature. Oxford: Oxford University Press. 